\title{
The "Modern Greek Maritime Policy", 1953-2018: A Critical Review of Its Legal, Economic and Institutional Framework
}

\author{
Alexandros M. Goulielmos ${ }^{1,2}$ \\ ${ }^{1}$ Ex-Professor of Marine Economics, Department of Maritime Studies, University of Piraeus, Athens, Greece \\ ${ }^{2}$ Ex-Head of Maritime Division of Business College of Athens, Athens, Greece \\ Email: ag@unipi.gr, am.goulielmos@hotmail.com, agoulielmos@bca.edu.gr
}

How to cite this paper: Goulielmos, A.M. (2018) The "Modern Greek Maritime Policy", 1953-2018: A Critical Review of Its Legal, Economic and Institutional Framework. Modern Economy, 9, 1190-1212. https://doi.org/10.4236/me.2018.97078

Received: May 4, 2018

Accepted: July 20, 2018

Published: July 23, 2018

Copyright $\odot 2018$ by author and Scientific Research Publishing Inc. This work is licensed under the Creative Commons Attribution International License (CC BY 4.0).

http://creativecommons.org/licenses/by/4.0/

\section{(c) () Open Access}

\begin{abstract}
We showed analytically the legal framework, which Greek flag administration established since 01/01/1953 with the long celebrated law of 2687/1953 for ships greater than 1500 GRT. All Greeks believe that this institutional framework contributed a lot to the expansion of Greek-flagged shipping. We also presented the tonnage tax payable by a Greek-flagged ship, with suggestions to modify it in a more proper manner. We dissolved the myth that Greek flag is a quasi or a flag-of-convenience, where ships do not pay taxes. We have stressed a number of facts: 1) the role that a Government plays vis-à-vis national shipping; 2) the freedom of actions which shipping needs; 3 ) the best legal framework required by shipping: in having permanency, being expandable as time goes by, protected by country's constitution, modified to provide more favorable terms and all these are legislated by 2 ministers outside parliament in a fast way to be ahead of any shipping crisis like that in 1981-1987. Law 2687 and "the ship registration approval action" are the products of a long traumatic experience-except in 1946-that Greek-flagged shipping had since 1830 from various governments-including that of El. Venizelos-and from 2 world wars.
\end{abstract}

\section{Keywords}

Greek Flag Legal Framework, Law 2687/1953 Article 13, Law 27/1975 and 1376/1983, Tonnage Taxation, Ship Approval Registration Action-Terms and Conditions till Early 2018

\section{Introduction}

The hallmark of modern Greek Shipping Policy has been put on with article 13 
of a piece of "legal, administrative and institutional nature", i.e. law $2687 / 1953$ [1], published in Government's gazette in end 1953 (10/11/1953). This was in force since 01/01/1953 for large ships. Article 13 aimed at attracting ships-larger ${ }^{1}$ than 1500 GRT-to Greek Flag. This policy called: "new Greek Shipping Policy"2 (Kyriasopoulos, 1958, [2]). Subsequent laws 27/1975 [3] and 1376/1983 [4] legislated for ships greater than 3000 GRT, implicitly recognizing the eventual failure of the original "size criterion".

Law (2687) not only wished to attract ships, but also wanted to invite foreign capital, and moreover to care for its safety after it has been imported into the country; as a result law's title was: for "investment and insurance of capital ${ }^{3}$ from abroad". It contained 17 articles. The law aimed specifically at attracting "productive investments", i.e. those, which had to help in the "development" of Greek economy, or to contribute to country's "economic progress".

The law (2687) has been considered by "Hellenic High Court", (decision

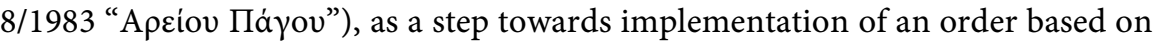
article 112 of the 1952 Greek Constitution. Thus, law's "increased power" derived from - and protected-by Greek Constitutions ${ }^{4}$ since 1953 and till this day. Greek Constitution is about to be revised in end 2019, but it is our belief that law 2687 will remain in force.

Worth noting is that inside and outside Greece was, and is, believed that a great deal of the progress of Greek-flagged shipping-today in the first 7 top global positions ${ }^{5}$ (Jan. 2017) -is due to the "legal and institutional framework" legislated by Greek Government in 1953, and to the par excellence instrument created, i.e. "ship's registration approval action" —SRAA - a permanent, but ever changing, law to provide more protection!

History proved that the nature of a political breeze blowing towards shipping greatly influenced national registries. The growth of ships under Greek flag was unique, especially between 1967 and 1981-under 2 different Governments: one belonging to extreme right (a military dictatorship), for 1967-1974, and one in right-wing, for 1974-1981, (“New Democracy” government) [5].

When socialists came to power (Oct. 1981) Greek flag retreated to almost $1 / 2$ of its power, i.e. from $43 \mathrm{~m}$ GRT (1981) to $20 \mathrm{~m}$ (1989) (Figure 1); this was a ${ }^{1}$ Since the law wished to attract only large investments (greater than $\$ 1 \mathrm{~m}$ at 1953 prices, we reckon), the size of a ship over 1500 GRT, should have this value. Law 2687 mentioned incidentally investments of $\$ 1 \mathrm{~m}$ (article 9, par. 2). If today we want to speak for a large investment, this should be greater than $€ 15 \mathrm{~m}$.

${ }^{2}$ Additionally, law 2928/1954 and the (unanimous) legal opinions of the "Legal Counsel of State" 513/1955 and 967/1956 (in full assembly) supported law 2687. Notable is that Greece in 1953 got out from a 4-year German occupation, 1941-1944, followed by a Civil War.

3"Capital" is: funds in foreign currency, machinery, materials, inventions (technical methods, knowhow, patterns, commercial and industrial trademarks etc.); and... large ships.

${ }^{4}$ Law 2687 rests also on article 35 of the 1952 Greek constitution (paragraph 2), following also the 22/1953 unanimous decision of a committee of MPs, and a proposal from the "Council of Ministers".

${ }^{5}$ https://www.ugs.gr/en/greek-shipping-and-economy/greek-shipping p.4.

${ }^{6}$ SRAA titled: "Approval of the terms regulating vessel (name) (or to be named...) (type...) (or under construction in shipyard-in-and hull number-), which is going to be registered in Greek flag according to law 2687/1953". 


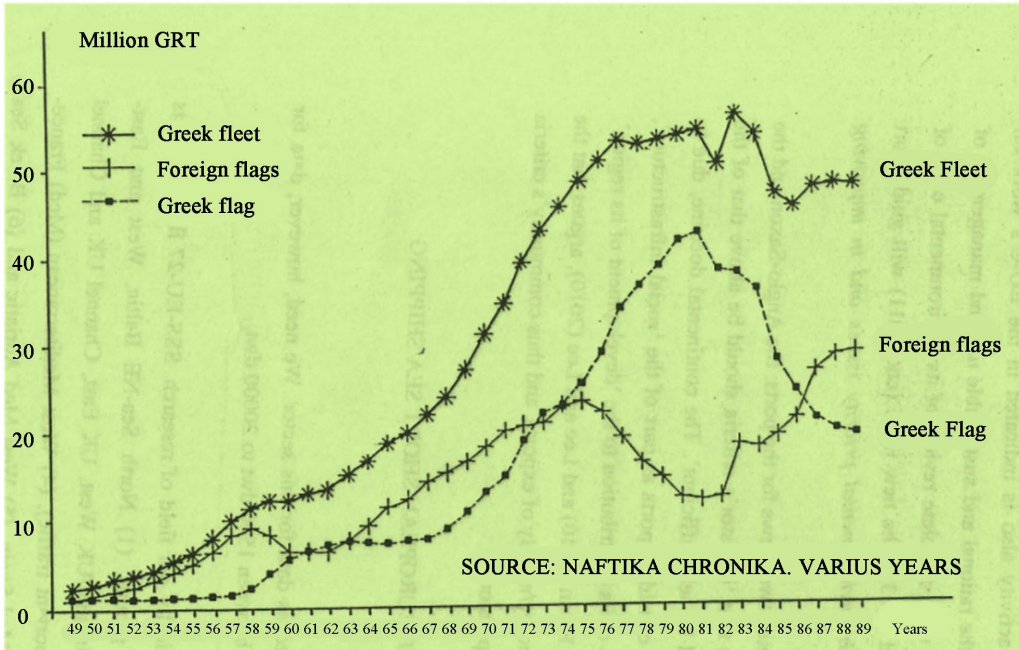

Figure 1. Total Fleet under Greek Control, Greek Flagged and Under Foreign Flags 1949-1989. Source: "Naftika Chronica”, Industry's monthly journal, various years.

result, we believe, of the fear that the status-quo of vessels flying Greek flag, would change at their expense... Socialists displeased shipping a little at the start, but later too much, with law 1376/1983 [4]. This law legislated that all "crew work length" will last maximum 71/2 months.

The whole purpose was to "recycle crew employment"-so that a larger number of crews, than hitherto, earn income, during the 1981-1987 deep shipping depression ${ }^{7}$. After all the role of Government in shipping matters is important, as it is important for shipping to have a friendly institutional and legal framework properly designed, which can be made also... permanent and also flexible, as Greeks did.

For the sector to be great-as the Greek-owned-however, it needs to be adaptive, and flexible to changing market conditions [6]. Shipping wishes to be as much as possible neutral with adverse political systems, like today's SYRIZA, and enthusiastic and helpful towards all kinds of right wing governments [5]. Shipping requires stability in its treatment, with no interventions from persons unfamiliar-i.e. from "shipping-less" people...

In understanding the law, we have to point out policies aiming at attracting foreign exchange inflow ( $\$$ or $\mathfrak{E}$ ) were and are important for Greek economy, suffering the whole post war period from an adverse trade balance. UK, in which shipping is part of the economy [7] in 1986 [8], earned $£ 3.3 \mathrm{~b}$, against $£ 3 b$ in 1974 from shipping. The Greek shipping foreign exchange inflow was $€ 14 \mathrm{~b}$ in 2006 and $€ 17 b$ in 2007 [9]. There is a jump of inflow amount between 1998 and 1999 from $€ 2.17 \mathrm{~b}$ to $€ 5.14 \mathrm{~b}$, as Bank of Greece modified the way maritime inflow has been calculated. In 2014, inflow was $€ 13.13 \mathrm{~b}$ and in $2016 € 7.81 \mathrm{~b}$ due to the continued shipping recession and capital controls in Greece. Between 2007 and 2016 shipping imported $€ 136 \mathrm{~b}$ against $€ 117 \mathrm{~b}$ of tourism.

${ }^{7}$ Crews when there is a crisis try to stay on board as long as possible on fear of losing this opportunity. 
A provision of SRAA, for which we disagree, is the "recent term" 22 , because if the scope of the law was to attract ships to Greek register for them to help economy's growth, then because they contribute to this in degrees, the any privileges provided had to be given also in degrees [10].

Law 2687 (article 13) and 27/1975, were not based on any kind of prior research. However, a regression we run (1) between the number of ships under Greek flag and foreign exchange inflow in \$ and (2) between the number of ships under foreign flags of Greek interests and foreign exchange inflow in $\$$, the coefficient of correlation was higher in the first case, $=0.92$, vis-à-vis 0.58 ; for 1948-1950-1989 [11]. This correlation justifies policies boosting the number of ships under Greek flag. In Jan. 2017 Greece covered $~ 24 \%$ in EU fleet $(74.5 \mathrm{~m}$ dwt) behind Malta of $\sim 32 \%$ and before Cyprus of $\sim 6 \%$.

We provided a historical analysis tracing the developments occurred in the legal, economic and institutional/administrative framework of Greek Shipping for the last 65 years, i.e. from 1953 till early 2018. This paper, we believe, will be useful for other maritime nations in the making.

The paper is organized as follows: next, is a literature review; then the flag-of-convenience is defined and the parallel registries are mentioned; next the Greek-flagged fleet and its growth is noted; then, the meaning of article 13 of law 2687 is presented; next, the freedoms provided to Greek-flagged ships by law 2687 after its publication are analyzed; next, the errors committed by the law vis-à-vis the nationality of her owner is presented; the controversial issue of Greek-flagged vessel's taxation on law 27/1975 is finally analyzed. Then we conclude; in an appendix we suggest how a SRAA has to be written.

\section{Literature Review}

Kyriasopoulos [2] presented and commented on law 2687 in his lecture at the "Institute of Shipping Research" at Bremen. He argued (p. 21) that "Greece took every possible measure to give shipping trade the same chances it enjoys under "flags-of-convenience" (p. 21)... (defined below). This is not entirely true.

Fisser [12] argued that if one brings the cost, (crew and operational), in line in all flags, the advantage of "flags of convenience" will be not so much on cost, but rather on "commercial freedom" to take action: Greece has, in 1953, given its shipping this freedom in every respect (italics added). He was right for Greece established nine (9) freedoms for Greek-flagged ships (Figure 2). These freedoms were deprived from Greek shipowners before 1952. After 1953 more freedoms and other matters settled (Table 1), and the terms increased to $28 \ldots$

Doganis and Metaxas [13] and Bergstrand [14] dealt with the phenomenon of "flags of convenience" among others, like ILO ${ }^{9}$ [15]. Greek flag was not considered as a flag of convenience, but as a quasi-one [16]. Metaxas argued that a vessel registered under Greek flag-implying also under law 2687-is owned by a

${ }^{8}$ The 19 "recent terms" were legislated after the 9 terms of the original 1953 law 2687.

${ }^{9}$ The convention on High Seas of 1958 stressed that the state must effectively exercise its jurisdiction and control in administrative, technical and social matters over ships flying its flag (in force since $30^{\text {th }}$ Sept. 1962). 


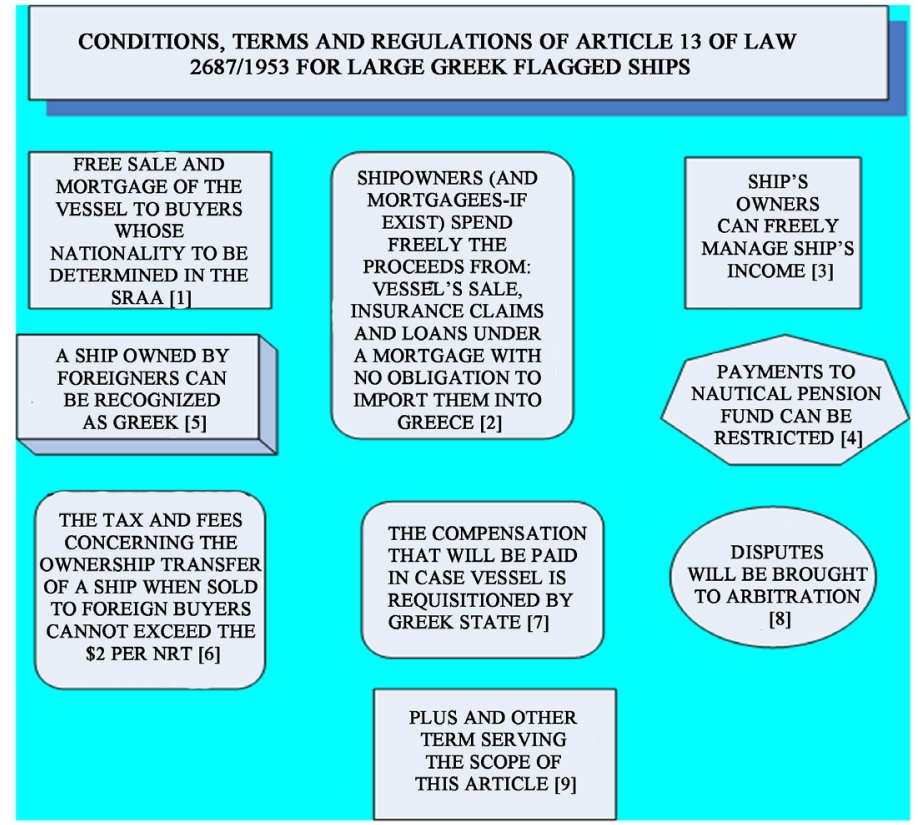

Figure 2. Source: author; prepared on the basis of law 2687/1953.

foreign company and considered by Greek State as "foreign capital" [16].

Karatzas and Ready [17] and Ready [18] mentioned what article 2 of the "Greek Private Nautical Law-GPNL" (3816/1958) requires for a ship to be registered under Greek flag: 1) the name and nationality of her owner, 2) appointment of a person domiciled in Greece authorized to accept $t^{10}$ service of process and document of title $\left.{ }^{11}, 3\right)$ the name of the vessel, 4) her international call sign, 5) her dimensions and tonnage $\left.{ }^{12}, 6\right)$ her means of propulsion, and 7) the horsepower of her engine (for engine-propelled ships). For ship's arrest-a precautionary seizure by creditors-which can be entered on ship's register; for ownership, the registration ensures that ship-owner's title is valid against $3^{\text {rd }}$ parties; for mortgages, the registration not only gives notice of creditor's interest in the ship, and so protects it against $3^{\text {rd }}$ parties, but also determines the priority between competing mortgagees. Accordingly to article 197 of GPNL: "a mortgage comes into existence upon its registration in the 'mortgage register' of the district in which ship is registered".

British accused Greeks [18], in line with UNCTAD’s report in 1981 [19], in relation: (a) to the freedom from fiscal obligations provided by "flags-of-convenience"13 by liberalizing tax concessions, and (b) the increases in Government assistance

\footnotetext{
${ }^{10} \mathrm{He}$ became also a "guarantor" (after 1960).

${ }^{11} \mathrm{By}$ which ownership is acquired.

${ }^{12}$ According to official measurement.

${ }^{13}$ Between 1939 and 1982, 10-flags of convenience-dominated, by achieving in 1982 a share of $27 \%$ of world fleet (!) (=425 million GRT) from $1.2 \%$ in 1939. In 1939 we had Panama and Honduras; then: Liberia, 1949; Costa Rica, 1953-1960; Lebanon, 1960; Cyprus, 1966; Somalia, 1968-1977; Singapore, 1968; Bahamas, 1970; and Bermuda, 1970 (Lloyd's Register of Shipping/Statistical Tables). Greece-under foreign flags—in 2001-used 42 flags! $1^{\text {st }}$ was Greece with 960 ships (26.5\%); then Cyprus, 681 (19\%); Malta, 653 (18\%); Panama, 590 (16\%); Bahamas, 191 (5\%); Liberia, 170 $(4.7 \%)$ and S Vincent \& Grenadines, $156(4.3 \%)=93.5 \%$.
} 
given by traditional maritime nations. Greeks followed the above policy under (a) above successfully-according to British-in early 1950s in an effort to repatriate a substantial number of Greek-owned ships operated under flags of convenience, with law 2687.

British argued [18] that law 2687, and the ministerial decisions issued pursuant thereto-approving the registration of individual ships-contained a package of measures enabling Greek owners to operate ships under Greek flag in a virtually tax-free environment (italics added). This is not entirely true. Commission ${ }^{14}$ of EU, following British, argued that the Greek tax regime is particularly attractive for shipping [20].

“Greek Shipowners Union's” legal advisor: Mr Daniolos G [21] said that important was the fact that Japanese shipbuilders showed interest in Greek shipping (in late 1960s). Japanese were not sure for the creditability of Greek shipping, and foreign banks did not trust Greek legal system, especially those in USA.

So, Citibank sent to Greece a team of 15 lawyers in early 1960s delivering a questionnaire to a large number of Piraeus lawyers for the purpose of: 1) understanding SRAA; 2) the way Greek legal system works and 3) what guarantees are provided etc. After a month, Americans were convinced and started approving loans. Japanese followed...

Japanese shipbuilders at that time took over eventually the top world position from British shipbuilders, as they became more competitive. Onassis [22] was the one to take advantage of this, adding to his fleet management also the principles of economies of scale, mass sister ships and using "other people's money".

Daniolos [21] confirmed that the most important matter to which Greeks shipowners owe their, by 1994, growth, was law 2987/1953, article 13. This helped Greek shipping to survive. Initially the law was conceived as having the purpose to secure lenders' interests-something true ${ }^{15}$ - but SRAA proved to be a top effective tool to serve Greek shipping with no time delay ${ }^{16}$.

\section{Flags-of-Convenience and Parallel EU Registries}

A flag of convenience is "the one whose government sees registration as a service to be sold to foreign shipowners for certain particular fiscal or other favorable conditions, which flag sells". This is not the bad part. The bad part is to sacrifice ${ }^{14}$ SEK (89) 921 final, 03/08/1989.

${ }^{15}$ In 1910, the Minister of Mercantile Marine, Mr. Epam. Empiricos, coming from Merchant Marine, published a law for "marine hypotheque" for the first and early time. This demonstrates how important is for the every time minister of merchant marine to be familiar with ministry's subject.

${ }^{16}$ This advantage, "PASOK Government" in 1981, in the case of law 1376/1983 [4], did not exploit. This law published in 18th July 1983, while it elected in end 1981 (21/10/1981); its first Minister of Mercantile Marine stayed only 9+ months in service, (resigned on 29/07/1982). The law titled: "Measures for facing-out shipping cycle and related provisions". Shipping crisis started in $2^{\text {nd }}$ semester of 1981 and ended in first semester of 1987. Political opponents said that law 1376 provided too little too late. But to be fair law 1376 provided cheaper foreign crews. The dearer foreign labor was a mistake of "New Democracy's" Government (since 1976-law 451/1976), which cost as estimated was $\sim$ \$600 m per annum unnecessarily to Greek shipowners! This flag's competitive advantage lasted till 1985-1986, when most European countries created “parallel registries” allowing cheap foreign crew. 
crew and cargo safety and to deteriorate crew working conditions in the flag-of-convenience - in comparison with national flag ${ }^{17}$.

The catalyst factor in the establishment of the $6 \mathrm{EU}$ "parallel registries" was the 1981-1987 deep shipping depression, which opened the door for the employment of foreign crew on board European fleets. Parallel registries in EU started by Norway (1987 NIS) and France (1985-6, Kerguelen Islands-FIS), and continued by Portugal (Madeira-MAR), Spain (Canary Islands-CSR), Luxemburg (1990), Germany (GIS), Gibraltar (GSR) and Denmark (1988; DIS).

Greeks did not establish a parallel registry, as... having ${ }^{18}$ one, since 1955, established by law 3170, article 46... Parallel registries-however-deprived Greek registry from the competitive advantage it had of cheaper foreign crews (since 1983).

Worth noting is that UK (2000) also prepared to adopt the tonnage tax system; i.e. tax on "fixed profit per day"... So, a small vessel up to 1000 NRT, pays $£ 0.60$ per day per 100 NRT or $£ 2190$ per year (MCA, rss@mcga.gov.uk). For a ship 30,000 NRT “tonnage tax" is $£ 36682.50$ per year. As ship size rises, tax tonnage coefficients fall. Ship's age etc. is ignored. So, Greek tonnage system-presented below-is more comprehensive and it ends to higher tax than UK. But even the better "Greek tax tonnage system" needs revision, as we have suggested below.

\section{Greek-Flagged Fleet and Its Growth}

The Greek-flagged fleet increased from 1953 (year of the law) till 1963, but the real increase started in 1957 (=400 ships; $1.6 \mathrm{~m} \mathrm{GRT),} \mathrm{i.e.} 5$ years after the law. And the real great growth of the fleet occurred since 1967-15 years after the law, when democracy temporarily ceased by the military dictatorship [5]. Also in 1975-1981 (=4000 vessels in 1980, 41 m GRT!), under a right wing government.

Socialists frightened ships away (Oct. 1981). For comparison, in 2001 Greek flag owned 960 ships of $\sim 57$ m DWT ( $~ 34 \%$ of Greek controlled fleet of $\sim 168 \mathrm{~m}$ dwt on 01/03/2001; or 33.5 m GRT).

Onassis [22] argued that he was the one to restore lenders' confidence in Greek shipping. But this was done also by legislative decree 3899/1958, establishing "preferred ship mortgages". Worth noting is that there is a substantial difference between an ordinary hypotheque, and a "first preferred" one, which latter allows mortgagee to take over management of the ship in the event of mortgagor's default, and dispose vessel in a private treaty, rather than in a public auction.

"Recent term" 16 in a SRAA states that the preferred mortgages have priority from all other nautical privileges by derogation ${ }^{19}$ from article 205 of the GPNL,

${ }^{17}$ The best prototype of a successful parallel register is Norway, where safety regulations remained the same in the 2 registries.

18“Ships under foreign flags can be furnished with ship's articles for registering Greek crew working on board".

${ }^{19}$ Plus article 1289 of the Greek Civil code in combination with article 204 of the GPNL and of any other existing or future law. 
by L D 3899/1958 - and from any other provision of Greek legislation in force-with the only exception the privileges of article 2 of "Brussels International convention"20 (1926) (given that these privileges are recognized by the Greek law system).

\section{The Meaning of Article 13 of Law 2687}

Article $13^{21}$, of law 2687, states the terms, which a vessel registered in Greek flag-after approval of her registration-, will have to comply with during her entire stay in the flag. It requires first the publication of a SRAA in Government's gazette. Article 13 contained 9 terms presented in Figure 2. By early 2018, a SRAA contains about 28 terms! This is an advantage. We reckon that SRAA's text has to be re-organized (the way proposed in Appendix 1) to avoid repetitions.

Above terms are analyzed below.

The Greek maritime policy separated ships into 2 categories in accordance with their size. This criterion of size, however, became obsolete as the size of ships increased by leaps and bounds since 1953, as shown in Figure 3 for the "Greek controlled" fleet, which is the tank from which "Greek flag" gets its ships. The average ship size was near 78,000 dwt in 2016.

As shown, the average size of ships, under, as many as 42 flags, owned by Hellenes, increased fast after 2000 and more than doubled, gaining exceptional

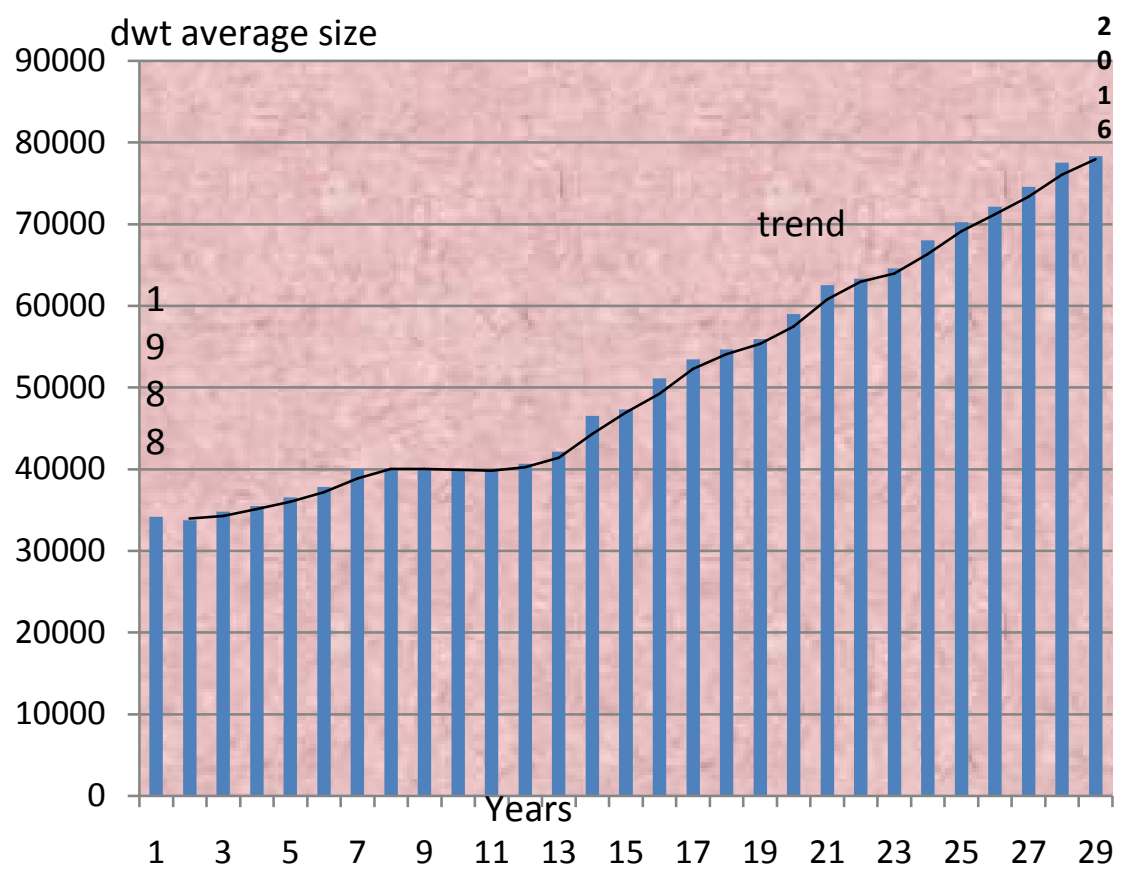

Figure 3. The average size of Greek controlled fleet, 1988-2016. Source: Greek Shipping Co-operation Committee, Greek controlled Shipping: an information paper, based on data provided to Committee by the LRS, yearly. Our calculations.

\footnotetext{
${ }^{20}$ This convention is unnecessarily written in French.

${ }^{21}$ Plus: paragraphs $2 \& 3$ of article 3.
} 
economies of scale. The law, the state, and shipowners, had to put an adjustable-over time-ship size. Thus ships under Greek flag are classed into: 1) "ships over 1500 GRT", under law 2687/53, and 2) "ships of less than or equal to 1500 GRT", under laws before $1953^{22} \ldots$ In 2001, the average size of ships in Greek flag was $\sim 35,000$ GRT and $~ 56,000$ GRT in 2017 (Jan.).

$\checkmark$ Analysis of the 9 original terms of article 13 of law 2687

The first 3 terms (Figure 2) provided "freedom of action", which owners of Greek-flagged vessels-in the past-deprived: (1) to sell the $\operatorname{ship}^{23}$ (to foreigners), with no permission required from Administration ${ }^{24,25}$; to register a mortgage on her. (2) To spend freely proceeds-with no obligation to import them into the country-from: a loan under ship's mortgage(s); her sale; her insurance compensation due to a marine accident ${ }^{26}$. These rights were valid equally also for ship's lenders ${ }^{27} /$ mortgagees (if any). (3) To manage freely vessel's revenue, (in foreign currency), without restriction.

Moreover, the contributions payable to Greek "Seamen Pension Fund"-NAT had to be fixed (term 4). This term, however, violated by the Greek Minister of Merchant Marine in 1986, who increased ${ }^{28}$ them despite disagreement of both the shipowners and the law. The law needed agreement between contracting parties-shipowners and the State-to rather reduce them... This was the $1^{\text {st }}$ blow against law 2687. Later came another minor one ${ }^{29}$. (Term 5) Recognizing ships owned by foreigners as Greek.

In addition (term 6), cared for shipowners for not paying "excessive" transfer taxation, and fees-given that the absolute amounts in \$ involved in the sale of a vessel were substantial, we believe. In the past, the transfer tax', e.g. for houses, was $11 \%$ on the value mentioned in the sale contract, which, however, is high in absolute terms in the case of ships. So the tax payable, and the fees due, for

\footnotetext{
${ }^{22}$ This criterion affected also the participation of owners in the relevant "ship-owners' unions"...

${ }^{23}$ To foreign buyers: natural persons or legal entities.

${ }^{24}$ In 1953 the nationality of buyers had to be mentioned in the SRAA (law 2687, article 13, paragraph a). Buyers had to come from 28 - 31 countries (1961-1975), and from areas: N and S Africa, British Commonwealth, and $\mathrm{N}$ and S America. Turkey included, and in 1963, also "Nationalistic China". For other countries, permission from minister of Merchant Marine required... In 1961, the countries permitted to sell to, were chosen by ship's owner...Since 1983 this requirement ceased (but a SRAA in 1994 had this requirement).

${ }^{25}$ To foreign buyers: natural persons or legal entities.

${ }^{26}$ Proceeds from ship's operations, and from insurance claims due to other causes than a marine accident, not obligatorily imported into Greece (except if the vessel obtained by foreign exchange in $\$$ or $\mathfrak{E}$ provided by the state); also, it concerns proceeds coming from changing flag.

${ }^{27}$ Lenders-having registered a mortgage — can freely dispose foreign exchange; a permission had to be granted by Central Bank of Greece if the vessel obtained by an $€$ loan.

${ }^{28}$ From $11 \%$ to $14 \%$ for owners, and from $8 \%$ to $9 \%$ for crew (total $23 \%$ from $19 \%$ ) ("Naftiliaki", 1987, summer). This illegal action dictated by the pressure of the deficits emerged in the fund. The fund received $€ 70 \mathrm{~m}$ from Budget in $2015 \ldots$ Certain mistakes in Fund's policy, committed by both "PASOK" and "New Democracy", contributed to. Government legislated law 29/1975 to support NAT.

${ }^{29}$ Another blow was given by Minister of Economy \& Finance, Mr. Stef. Manos, and his circular, who decided to terminate tax exemptions of law 27/1975 on ship repairs, from 01/01/1992. The circular became soon void, as this law (articles 1-11) is part of SRAA, and can change only towards providing an improved status.
} 
transfer of vessel's ownership, sold to foreigners, determined at \$2/NRT maximum.

(Term 7): this also comes from bad experience Greek shipowners had during $2^{\text {nd }}$ World War from ship's requisitions, and it determines the way compensation will be paid in case of a war. (Term 8) disputes from the implementation of SRAA will be solved by Arbitration.

The super term, however, was number 9 (Figure 2), establishing the flexibility and the adaptability of the total legal framework over time; surely, this is based on the initiative of shipowners on the one hand, and the state to approve his/her requests, on the other. Term 9 establishes also the ability of the administration to include and any other term serving the purpose of article 13, beyond the 9 ones mentioned indicatively. This term 9 we consider to be a genius contribution of law 2687, article 13, to shipping.

\section{$\checkmark$ Epilogue}

The whole effort of legislating law 2687/1953 may sound unnecessary for those outside the sector. But we may remind that the Greek state a couple of times conceived shipping as the "chicken" laying the "golden eggs". The Greek state each time it got out from a World War, or a crisis, in a state of devastation undoubtedly, looked forward... to tax shipping... and restrict certain of the freedoms the sector had or required. This is so that though the Greek ships "physically" were lost up to $60 \%-70 \%$ during wars from war causes, they were insured in the UK insurance market for this happening.

\section{Freedoms Provided to Greek-Flagged Ships by Law 2687 after Its Publication}

Table 1 presents the terms that appeared after 01/01/1953.

As shown, the terms increased since 1953 from 9 to 28 .

The main job that law 2687 did was to equalize ships with foreign exchange coming from abroad. Article 13 in effect means in today's terms that: if an amount in foreign currency, in $\$$ or $\mathfrak{E}$, is invested in a ship-of a size today greater than $40,000 \mathrm{dwt}$-and given that an application ${ }^{30}$ is submitted for the ship to

\footnotetext{
${ }^{30}$ Ship's application has to be submitted by her representative-and guarantor-in Greece to "Greek

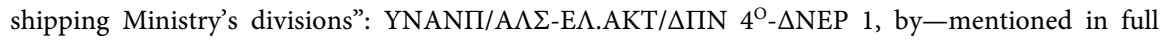
name and with his/her father's name-the representative of vessel's "management company" (named) representing ship's "owning company" in Greece (named) with head office established abroad (place mentioned), and being also her guarantor (since 1960). The information required is: owning company's name, place of company's head office, ship's flag, ship's name in Greek and in English, (and possibly her ex name), GRT, NRT, country and year of built; also the purpose of the application has to be stated (=which is for the ship to be registered under Greek Flag under law 2687/1953). The application can be filled and for a vessel under construction (then hull number is mentioned, shipyard and country of build, type of vessel, and name, in which she will be registered). It is possible for the ship to have obtained "provisional shipping documents" and fly Greek flag already, in which case registration starts from this day. A recent (2017) SRAA mentioned 9 prior decisions, decrees or laws, one signed by the President of the Democracy, one by the Prime minister, and 7 others by various ministers. The SRAA is really an "agreement" between a private person-the shipowner-and the Greek Government. This is the reason why a SRAA is also subject to arbitration. Shipowner applies, state approves, agrees and guarantees.
} 
be registered under Greek flag, and approved by government's 2 ministers (mentioned below) - is considered-by law-foreign capital, imported into the Greek economy... This is an important metaphor and equalization that the law has made...

Table 1. Freedoms etc. provided to ships registered in Greek Registry after 01/01/1953 by Law 2687 contained in the SRAA.

\begin{tabular}{|c|c|}
\hline $\begin{array}{c}\text { Change of flag freely-"recent term" } 1 \text {. The change of Greek flag needs } \\
\text { a specific procedure however-"recent term" } 1^{31} \text { too }\end{array}$ & Free chartering of vessel_"recent term" 1 \\
\hline Insurance ${ }^{32}$ of vessel done freely & Vessel's seizure $^{33}$ for any reason and cause from \\
\hline —“recent term" 6. And for War Risks_-"recent term" 6 too & Greek state etc. is not allowed-"recent term" 7 \\
\hline Specifications of hull and machinery ${ }^{34}$ - "recent term" 8/paragraphs 10 - 11 & Labor issues-“recent term" 8 \\
\hline Ship's taxation-"recent term" 12 -presented below & $\begin{array}{l}\text { The ship is permitted to register on her } \\
\text { "preferred mortgages"- "recent terms } 19 \text { and } 20 " .\end{array}$ \\
\hline Provisions for Ship's company-“recent term" 16 & Disputes solved by arbitration_-"recent term" 21 \\
\hline $\begin{array}{l}\text { No modification or amendment to a SRAA is } \\
\text { allowed without the consent of the shipowner and the } \\
\text { lender/mortgagee- "recent term" } 22\end{array}$ & $\begin{array}{l}\text { Provisions on loans with mortgage in Greece from Greek } \\
\text { organizations or banks-“recent term" } 23\end{array}$ \\
\hline Ship's ownership transfer-“recent term" 24 & Allowances of law 2859/2000 on VAT article 27-“recent term" 25 \\
\hline $\begin{array}{l}\text { The shares of a ship-owning company can be passed to a holding company } \\
\text { - i.e. this is a "permission for listing"-"recent term" } 26 . \\
\text { (This term should be put together with those } \\
\text { terms referring to the "specific shipping company") }\end{array}$ & $\begin{array}{l}\text { SRAA becomes in force upon... } \\
\text { (date)_-"recent term" with no number-27? }\end{array}$ \\
\hline $\begin{array}{l}\text { Decision (SRAA) to be published in } \\
\text { Government's gazette-“recent term with no number" }-28 \text { ? }\end{array}$ & Date: \\
\hline
\end{tabular}

Source: based on SRAA 10/03/2017.

${ }^{31}$ The dis-registration of a vessel from Greek flag — with a purpose to fly another flag—is done "automatically", if a declaration in writing—coming from ship's owner, and with mortgagees' agreement in writing-if any-is submitted to "Ministry of Merchant Marine and Island policy" or to any salaried Hellenic Consulate or Coast Guard abroad. This should be accompanied by receipts from the competent Hellenic services, which will verify payment, up to the date of declaration, of: 1) taxes due from vessel currently or from the past, 2) telecommunication expenses in general, and those of Greek Organization of Telecommunications, due by vessel; and 3) contributions due to "Nautical Pension Funds". Alternatively, the declaration can be accompanied by a letter of guarantee for English Sterling 55,500-or the equivalent in \$-on a British or an USA bank. This amount changes from time to time. Greek services are obliged to dis-register the vessel, and the harbor-master in which vessel is registered, or any Greek salaried Consulate, or Coast Guard abroad, are obliged to supply a certificate of vessel's dis-registration from Greek flag. For paying-out the debts of the vessel at the time of declaration for dis-registration (=change of Greek flag), or in case of voluntary or involuntary sale of the ship to Greeks, or foreigners, or in case she sunk, totally responsible for above payments is also the guarantor in Greece of ship's owner-resigning from the benefit of the plea of preliminary proceedings against the main debtor.

${ }^{32}$ Vessel is freely insured by her owner; even if she is requisitioned by Greek government, and even if a latter law rules differently. Vessel's insurance against war risks - in case of war involving NATO-has to follow a specific procedure; and even if the ship is covered for war risks during war, and independently for any extra insurance for war risks done freely by her owner, on his/her free judgement in the free insurance market, the procedure stays. Insuring the vessel (when NATO is involved) this has to be done exclusively with "S. A. Hellenic Maritime Insurances"-against war risks-(based in Piraeus). Bear in mind that an agreement since 01/09/1976 between Greek state and the above S. A. applies. Also, for the above insurance company are valid laws: 551/1970, due to law 400/1970, 2190/1920 and 4237/1962-except for the provisions referring to income tax; bear also in mind that the strict implementation of the above mentioned agreement, and the operation of the above S. A., are under a specific legal framework prepared for ship's interest.

${ }^{33}$ Ship's seizure is not allowed for any reason by Greek state or by state's organizations. Exception holds only for debts of the ship due to by her owner.

${ }^{34}$ This term should be separate with own number. 
The law entitles the most relevant ministries to approve the ship's registration, i.e. Ministers ${ }^{35}$ of "National Economy", and of "Merchant Marine"36 - who is a permanent member. The Ministry of Merchant Marine, as the whole matter of the registration of a ship is in its exclusive jurisdiction, is well entitled to approve a SRAA". Moreover, the "Ministry of Economy" is entitled, or has to be, we believe, to see whether a SRAA contributes to country's economic growth ${ }^{37}$. This should be all.

Other ministries involved we reckon are redundant and may cause delay in the whole procedure (e.g. law 4170/2013; mentioned in footnote below). In March 2017, a SRAA was signed by: the "Minister of Shipping and Island Policy"; the deputy "Minister of Economy and Development"; the Undersecretary of "Economy and Development" and the Undersecretary of "Economics/ Finance"... The SRAA has to be published in Government's gazette.

A SRAA-signed by the Ministers-has to be published in Government's gazette, usually taking 1 to 3 months-under normal circumstances-from date of application. A SRAA has no need to follow a Parliamentary procedure. SRAA is a powerful law established and published by a procedure carried out by 2 or so ministers, outside Parliament.

This is important for in case of a shipping crisis measures should be taken fast $^{38}$. A SRAA is also a "guarantee" provided by the state to a shipowner, confirming that SRAA's regulations are permanent and irrevocable during vessel's stay in the flag. Moreover, the terms and conditions in a SRAA cannot be modified without the consent of ship's owner ("recent term" 22). A SRAA is under constitutional protection, as mentioned.

Article 13, paragraph 2, of law 2687, had to be interpreted authentically by a subsequent law-law 2928/1954-in saying that: "deviations ${ }^{39}$ from existing law provisions are permitted to be included in a SRAA"... This meant that the Ad-

${ }^{35}$ A recent (2017) SRAA mentioned 9 prior decisions, decrees or laws, one signed by the President of the Democracy, one by the Prime minister, and 7 others by various ministers. The SRAA is really an "agreement" between a private person-the shipowner-and the Greek Government. This is the reason why a SRAA is also subject to arbitration. Shipowner applies, state approves, agrees and guarantees.

${ }^{36}$ Paragraph 1, of article 67, of law 4170/2013, gave the authorization to sign a SRAA to a specific section of the ministry of finance, which has to check it on the basis of a pre-approved text (sample) of it. This surely is redundant.

${ }^{37}$ The ministry of finance in end 2013 was in favor of a standard text for the SRAA, and wanted to speed-up its signature in 4 working days under normal circumstances (ministerial decision 1239/2013 GGI B 2864/11.11.2013). This decision, however, implicitly determined also a dominance of the ministry of finance (tax income department of the General division of Revenue taxation) over the ministry of mercantile marine. This could be right for only that part of SRAA dealing with taxation, we believe.

${ }^{38}$ During the 1981-1987 shipping depression, Greek Government drafted certain measures in 1982-law 1376 - which by following the parliamentary procedure took about 1 year to be published (in 1983, July 18th). Worth noting is that law 1376 did not concern ships greater than 1500 GRT as law 2687, but greater than 3000 GRT (article 1) (!) in line with law 27/1975.

${ }^{39}$ Deviation is permitted from articles 233 plus, and 263 plus, of "Commercial Law", of "Civil procedures law", and from any other existing legal regulation. Deviation is permitted from articles 243-262 of "Commercial Law" and the applicable articles of "Civil Law". 
ministration in publishing a SRAA can include and any other term and provi$\operatorname{sion}^{40}$, even if this deviates from the existing legal terms in force (existing regulations) of the "Civil, Commercial, and Procedural" Law, and also to those terms and provisions related to "Public Order" (published in 22/07/1954)! This is a magnificent interpretation.

Another great service of law was to equalize-in a ship's loan default case-ship's owners with ship's mortgagees (= bankers). A first "preferred mortgage" entitles the lender to step in ship's owner shoes, and take over her management. This term secured the rights of the mortgagees and assured that Greek shipowners meant honest businesses. Foreign banks thus-since 1960s-started to finance ${ }^{41}$ Greek-flagged vessels and to establish branches in Piraeus.

\section{The Error Committed by the Law Vis-à-Vis the Nationality of Her Owner}

Law 2687, article 13, did not require that the ship had to be owned by Greeks, and they had to have a majority interest in the capital of ship's owning company. However, flag Administration in all SRAAs ( $1^{\text {st }}$ page), mentions that ship's representative in Greece-in a dated written declaration-“declares that ship's owning company covers Greek interests—by majority—in its capital”...This is repeated in the approval of ship's registration: "the vessel will be owned by the company so and so (name), established in (name of place), which covers-in accordance with the statement of the (so and so) (full name and father's name) representative of company (so and so), representing ship's owning company in Greece, Greek interests in $\%>$ than $1 / 2$ of its capital...

For the third time, in "recent term" 24, SRAA specifies (early 2018) that an existing SRAA remains in force in case vessel's ownership is transferred. Meaning that a transfer to another Greek natural person, or legal entity, or to a foreign legal entity, is allowed, provided they cover, by majority, Greek interests... This has to be reflected also in ship's registry-in case of a transfer to a foreign legal entity-by appointing a guarantor, and by submitting evidence that it covers Greek interests by majority. If the ship has registered on her a mortgage, the legal action towards ship's sale must comply with article ${ }^{42} 202$ of GPNL (law 3816/1958).

The spirit of law 2687 was for a vessel to be in a foreign flag prior to her registration to Greek flag-we reckon-no matter who owned her. But, the 3 efforts

\footnotetext{
${ }^{40} \mathrm{~A}$ SRAA can specify (indicatively) also: the age of the vessel, the freedom of registering a mortgage on her, the declaration that the decisions etc. of foreign Courts are enforceable in Greece, and the rights of lenders, who have registered a mortgage on her.

${ }^{41}$ One reason of the great achievement of shipping under Greek flag and under foreign flags of Greek interest (Goulielmos, 2017, [6]), was banking finance-or as Onassis said-“other people's money". This permitted the growth of Greeks by leaps and bounds. Another reason was economies of scale coupled with adequate demand, par excellence for tankers, till oil crises.

${ }^{42}$ Meaning that a legal act aiming at the sale of a mortgaged vessel resulting in the loss of Hellenic nationality-if done with no consent of ship's mortgagee-is invalid.
} 
of Administration in all SRAAs introduced an inevitable confusion ${ }^{43}$. Law should have specified from the beginning that in the case of ships to be registered under Greek flag, their Greek owner must ${ }^{44}$ have interests by majority in ship's company capital...

Also a SRAA may cease- "if it is considered by the administration that the ship in future will contribute nothing ${ }^{45}$ to the development of national production-and the ship thus has to be dis-registered immediately from Greek Registry, if free of a mortgage..." First, a ship does not contribute to national production, but to national income, and important is her currency-in $\$$ or $\mathfrak{E}$-inflow, and the employment she provides to Greek crew.

Obviously, there is an insistence of flag administration in SRAAs for ship's company capital to belong by majority to Greek interests per mare per terra. Relevant recent term 24, however, has to be re-stated, we believe ${ }^{46}$. Certain owners have argued that the fact that a ship they bought was under law 2687 influenced her price...

Flag administration obviously found it inconvenient to "protect" a ship owned financially-by majority_by a shipowner of non-Hellenic nationality... It tried to avoid for the flag to be accused as flag-of-convenience, if ship's capital belonged to foreigners by majority. It would be simpler, if ship-owning company's capital confirmed as belonged by majority to Greek interests, by ship's owner in writing, bearing the consequences of the "law for a false declaration" (law 1599/1986). Alternatively, flag administration could decide that the ships eligible for applying for Greek flag under law 2687, are only those "owned by Greek parent companies by majority", "which are also greater than 40,000 dwt".

\section{Tax on Greek-Flagged Ships under Law 27/1975 [3]}

True is that Greek shipping companies were left out of "income taxation", and the tax authorities focused on ship, due to their failures ${ }^{47}$ in the past to determine the income of shipping companies, (first through charter parties), (law 1880/1951). Greeks adopted the "tax on tonnage" system and "age" plus "infla-

\footnotetext{
${ }^{43}$ Moreover, recent term 24 specifies certain additional peculiar-in our view-requirements in case a ship-owning company-in the name of which a SRAA is published-sells to a foreign entity--to which ship's ownership will be transferred-her SRAA may cease... on information gathered by Administration-and based on its free judgement-as far as the matter of company's cover (in its capital) Greek interests by majority is concerned...

${ }^{44}$ We reckon that warnings-as the above-should not be mentioned in a SRAA, as the State in a SRAA, guarantees the terms that a vessel has to comply with during her stay in the flag. Any prerequisites of approval of an application-something altogether separate, and of a prior matter to registration-should be published in Government Gazette, as a law, to be known to all interested in - before applying-for a Greek flag.

${ }^{45}$ This means for the ship to inflow less than the equivalent of $€ 50,000$ per year in the country.

${ }^{46}$ In a way of not throwing suspicions that a ship-owner, who bought a ship, could deceive administration by not having Greek interests by majority in the capital of ship's company, especially on the basis of ... information gathered by administration etc., without the buying owner knowing in advance where/how this information has to come from...

${ }^{47}$ State at a time between abandoning its efforts to determine the taxable income of Greek shipping companies, adopted the concept of "presumptive income"...
} 
tion/currency devaluation" in 1975 [3]. However, after 1985-6 became the standard taxation system in almost all EU countries-depriving Greek shipping from a competitive advantage...

Taxes on ships under a specific flag are a very crucial factor, as they can provide to a flag a competitive disadvantage. Table 2 indicates what a vessel paid in 6 popular flags, and in Greek flag, in 1994, for a hypothetical ship of 30,000 GRT and similarly for 10 registries in 2002 for a 36,781 GT vessel. "Tax on profits" is zero $^{48}$ in all these registries.

As shown Greek flag pays taxes many times higher than any flag-of-convenience. Greek-flagged ships pay tax in a combination of their size and age (plus inflation and devaluation of $€$ ) on the basis of law 27/1975 [3] as follows (Table 3, Table 4).

The above are multiplied, in each size class shown below, by the following coefficients, which did not change since 1976:

Thus a vessel of 10,000 GRT and 4.99 years had to pay tax $\$ 0.53$ times 10,000 GRT $=\$ 5300$ times $1.2=\$ 6360(1976)$; and in $2007=\$ 12,080$ times $1.2=$ $\$ 14,496$, i.e. more than double after 3 decades. Tax may be paid in $\$$, $€$ or $£$ in 4 installments.

Table 2. Taxes paid p.a. in \$, in 1994, by a ship registered in 6 popular Registries and in Greek flag, and tonnage tax in 10 registries in 2002.

\begin{tabular}{ccc}
\hline Flag & Tax per year $1994 \$$ & Annual tonnage tax $\$ 2002\left(^{*}\right)$ \\
\hline Cyprus & 6000 & 6510 \\
St. Vincent & 3550 & 2323 \\
Panama & 3000 & 3000 \\
Liberia & 1200 & 6123 \\
Bahamas & --- & 4437 \\
Malta & --- & 4467 \\
Greece & 61,380 & --- \\
Marshall islands & --- & 7356 \\
Cayman islands & --- & 4654 \\
Cambodia & --- & 2323 \\
Belize & --- & 3500 \\
\hline
\end{tabular}

${ }^{*}$ ) Source: Lloyd’s Ship Manager, Jan. /Feb. 2002, pp. 46-47. Note: certain registries had heavy initial registration fees, like Bahamas, which in 2002 had $\$ 20,904$. Registries compete one with the other over tonnage taxes and other charges. Some tonnage taxes were kept steady over long periods of time as shown above.

${ }^{48}$ Ship's owner, or the shareholders and partners of a Greek or foreign ship owning company, of any type, are exempted from tax on income coming (from profits) from ship's operations; similarly, they are exempted from the income coming from dividends from shares or from establishment titles in the ship-owning company issued to bearer, or registered for, and from any tax, which can be imposed in future. Also they are exempted from tax on the surplus value coming from the sale of the vessel or from her insurance compensation-which is paid as a dividend or as an excess value of shares, when company ceases to exist, or from the excess value, which came from the sale of company's shares by her shipowner. Also the profits paid in money or in kind of the co-owners in case of a "joint ship ownership company" are exempted from stamp duty; also a stamp duty is not required for any kind of a "statement of accounts" ("recent term" 13). 
Table 3. Tax payable by Greek-flagged ships in 1976 and in 2007, \$ per GRT.

\begin{tabular}{cclc}
\hline & Ship's age-years & \multicolumn{2}{c}{ \$ per GRT-Tax in 1953/\& 2007 } \\
\hline $0-4$ & (suggestion 0 - 4.99) & 0.53 & $1.208\left(^{*}\right)$ \\
$5-9$ & $($ suggestion 5 - 9.99) & 0.95 & 2.166 \\
$10-19$ & $($ suggestion 10 - 19.99) & 0.93 & 2.120 \\
$20-29$ & $($ suggestion 20 - 29.99) & 0.88 & 2.006 \\
30 & and over & 0.68 & 1.550 \\
\hline
\end{tabular}

${ }^{*}$ ) Coefficients increase by $4 \%$ per year, since 1976 . Source: law 27/1975 [3].

Table 4. Classes of ship's size in GRT and the coefficients of tax to be paid in relation to Table 3.

\begin{tabular}{cc}
\hline Ship's size in GRT & Coefficient \\
\hline $100-10,000$ & 1.2 \\
$10,001-20,000$ & 1.1 \\
$20,001-40,000$ & 1.0 \\
$40,001-80,000$ & 0.9 \\
$80,001-$ and over & 0.8 \\
\hline
\end{tabular}

Source: law 27/1975 [3].

Also Greek-flagged ships larger than 1500 GRT do not pay inheritance tax ${ }^{49}$. Moreover, article 107 of the 1975 Greek Constitution provided constitutional protection [3], concerning the taxation of "category on $\mathrm{e}^{50 \text { " }}$ ships. The law except for distinguishing ships in two classes on the basis of their size, introduced also a distinction between ships existing under Greek flag on or before 21/04/1975, for which is in force law 800/01-12-1970, and those on 22/04/1975 and after, where law 27 is in force (for ships above 3000 GRT).

Moreover, the "basic (law 27) and special (law 29/1975)" taxes can be reduced for the time ship was laid-up in current or previous year (for repairs etc.) after the first 2 full months, and on evidence submitted. "Cruising ships" and "ships in liner services" pay $1 / 2$ taxes, as well as "fishing ships" pay $75 \%$ less. The tax due is paid equally in February, June, September and December.

$\checkmark$ The distortion introduced in taxation in 1990

In 1990 the Minister of Merchant Marine reduced tax for Greek-flagged ships over 40,001 GRT and till 80,000 to $1 / 2$, and to $75 \%$ for ships of over 80,001 GRT.

\footnotetext{
${ }^{49}$ Here the provisions of part c of paragraph 1 of article 29 of law 27/1975 apply ("recent term" 14). The article 9 of the C L 465/68 (par. 1-3) and article 9 of law 509/70 (par. 1-3) ceased, apart from above provisions for the exemption from inheritance tax, from vessels, for shareholders or portion holders of Greek or foreign ship-owning companies for all ships > 1500 GRT.

${ }^{50}$ It concerns the engine-propelled dry cargo ships, tankers and reefers $>3000$ GRT. Similarly, iron-made ships between 500 and 3000 GRT, if they serve foreign ports or operate between such ports. Similarly, Passenger ships reaching foreign ports or operating between foreign ports. Also, Passenger ships > 500 GRT exclusive in cruises etc. And for the first time the floating drilling units > 5000 tons light weight (equal to 5000 GRT for the law) and floating refineries and floating warehouse etc. >15,000 GRT.
} 
This action was obviously unfair for ships from 3000 GRT till 40,000! Moreover, a younger vessel seems to pay a higher tax by reaching her 5 years, and lesser by reaching her 30 years, which is right.

A vessel 40,000 GRT 1 year old pays \$41,925 tax, while a ship 3 times larger pays only $\$ 67,275$ (same age). As a result, we have to think the philosophy of this taxation system. Is the larger ship more profitable? Is the older ship less profitable? Have the ships to pay more accordingly to inflation? The answer is yes to all three questions.

A vessel 5 years old of 20,000 GRT she paid \$40,204 tax in 1997, and when she doubled her age, paid almost the same (!) \$39,573; and when she doubled her size paid almost double, i.e. $\$ 75,164$. So, this taxation can be more fair, we reckon, if age reduces tax and size increases it... The present structure does exactly the opposite... In addition, a better measure for profitability is the $95 \%$ of ship's dwt, instead of GRT/NRT.

We suggest taxation to be modified as shown in Table 5 .

As shown, older ships pay less tax and larger ships pay more. In addition, the law required that the coefficients of age would increase $4 \%$ p.a. for inflation and for a hypothetical devaluation of national currency... $€$ now. But this provision increased substantially the tax to be paid, e.g. 4.3 times up (from $\$ 14,000$ to $\$ 60,000$ for a vessel of 25,000 GRT and 15 years old), between 1976 and 2007!

So, we suggest this $4 \%$ increase to be based on actual inflation of the year before, not that of the Greek economy, but of the globe, as this is given e.g. by IMF. Moreover, this \% of inflation at $4 \%$ was high due to current depression after end-2008, and the devaluation of national currency, after 2001, had to mean the devaluation of $€$ against $\$$, which was less than $4 \%$ per annum ${ }^{51}$.

There is no available space to deal with "recent terms" 16 - 18, something we will attempt in another paper.

\section{Findings and Analysis/Discussion}

Important is the adaptability of the law. The main purpose of law 2687 article 13

Table 5. Proposed taxation in a more fair way on age and size of Greek-flagged ships.

\begin{tabular}{cccc}
\hline Age classes & \$ per GRT/(1975) & Size classes & Coefficient/1975 \\
\hline $0-4.99$ years & 0.95 (against 0.53 ) & $100-10,000$ & 0.80 (against 1.20) \\
$5-9.99$ & 0.93 (against 0.95$)$ & $10,001-20,000$ & 0.90 (against 1.10) \\
$10-19.99$ & 0.88 (against 0.93 ) & $20,001-40,000$ & 1.00 (against 1.00) \\
$20-29.99$ & 0.68 (against 0.88$)$ & $40,001-80,000$ & 1.10 (against 0.90) \\
30 and over & 0.53 (against 0.68 ) & 80,001 and over & 1.20 (against 0.80) \\
\hline
\end{tabular}

${ }^{51}$ In case when a sale of a whole portion of a Greek-flagged ship, or of her fictitious share, takes place to Greek or to foreign natural or legal entities, there are no transfer taxes or stamp duties (recent term 14). If a ship contributes to the capital of the shipping company, is exempted from tax or fees —according to law 3415/1955 (article 4 par. 2) and 1676/1986, articles 17-31. Law 4419/1964 is still valid. There is no need for a confirmation of the action of ship's ownership transfer (article 5, par. 2, of the codified law 187/1973 of the Public nautical Law) due to buying her abroad in a Greek Consulate. 
was to provide to shipowners freedom of action in shipping businesses. Worth noting is that in the past certain state's interventions-most of the time-harmed-economically-Greek-flagged shipping, except in the case of buying the 107 ships for Liberty (1946).

The "recent term" 24 is controversial as it is, and it could only say that ship's ownership can pass to another Greek natural person or legal entity or foreign legal entity etc., but for the ship to obtain a SRAA, has to apply for it again, even if she had one before, or the change of ownership of the ship requires an application for a new SRAA.

It could also be wiser, for us, if in the SRAA was stated the exact \% of the capital that Hellenes hold in a ship-owning company ${ }^{52}$. The important for the law was ships to be registered under Greek flag, obviously to boost Greek Registry, and benefit national economy from foreign currency inflow, no matter who owns them. Moreover, term $\varepsilon-5$ th-in law 2687 recognized already-as Greek-also ships belonged to foreigners...indicating original law's intention.

The size determination of vessels by law 2687/1953 had the purpose to focus only on important investments, of $€ 15 \mathrm{~m}$ in today prices, we reckon. But we have to solve this paradox today by proposing in all subsequent SRAAs ships to be considered for registration under law 2687, article 13 , to have a value of at least $\$ 15 \mathrm{~m}$, adjusted by annual world inflation.

The law treated two kinds of capital-money in foreign currency-e.g. \$ or $\mathfrak{E}$-imported into the country, and capital embodied in a foreign-flagged ship of over 1500 GRT, allowed to be registered in Greek flag-as equivalent. But a vessel registered in Greek flag does not import into the country capital at the time of her registration, but eventually, and little by little, through her expenses paid in Greece in $€$, derived from \$. Flagged-vessels promote country's prestige, which greatly matters politicians. Also ships belong to an export shipping industry for Greece.

A ship registered under law 2687, article 13, not only has to conform to terms mentioned in it, but also to those mentioned in the SRAA, 65 years after law 2687. This property is the super function ${ }^{53}$ of the law, which made the law adaptive and flexible to changing circumstances...

The shipowner, at any time, requests changes in the legal framework concerning his/her ship, (greater than 1500 GRT), registered under national flag, and the state approves them. The state has the right to reject a certain term, and is not obliged to give an explanation-but if an explanation is given, then the "Supreme State Court of the administration law" can examine it for wrong legal judgement of the Ministry.

Another clever regulation was the one saying that any better terms and regu${ }^{52} \mathrm{~A}$ case existed where the owner, though foreigner, registered his/her ship under Greek flag under article 13 of law 2687; this was based on par. 1, article 10, of the law ruling that: "companies established using foreign exchange capital are treated equally favorable as other similar firms in the country".

${ }^{53}$ The law with paragraph 9 ruled that a SRAA may contain: "and any other term, besides the ones mentioned already indicatively, which serve the scope of article $13 . .$. . 
lations granted to a vessel, these should be extended to all other existing vessels, if applied for by their owners. This is the "recent term" we object, though we understand its inclusion. Important is also that the rules of the SRAA are guaranteed by the state so that to be permanent, and to be modified only with the consent of ship's owner, and if the change provides more...

Article 13 is an ingenious "metaphor", where a vessel, compared with a shore investment, is a "temporary investment" linked to national economy only for the time ship's registration lasts. Moreover, this investment in ships has its working place, not in Greece but...abroad, though one may say that a ship under Greek flag is Greek...land.

Shipping under Greek flag provides employment to Greeks, pays tonnage tax-estimated as round \$15 m p.a. on average based on 1989-1993 data-as well as other contributions for nautical education and crew pensions etc., and contributes to foreign exchange inflow, something very important as Greece has a chronic deficit in its balance of trade, and thus it is important to have proper exports, including shipping services offered in cross-trading. Personally, I want at least $\mathbf{5 0 \%}$ of dwt tonnage owned by "Greek parent companies" to be under Greek flag. In 2001 this was only $34 \%$ and in 2017 this fell to 26\%.

Greek-flagged ships are not taxed on the basis of their freight earnings from current operations, but on the basis of their tonnage in conjunction with their age, and the inflation/currency devaluation of $4 \%$ p.a. It is recommended, however, for the taxation legislation to be simpler and more comprehensible and if possible to be re-written in a codified manner. Changes in taxation for it to be fairer were given.

\section{References}

[1] Law 2687/1953 about: Investment and Insurance of Foreign Capital.

[2] Kyriazopoulos, I. (1958) The New Greek Shipping Policy. Lecture 1, Institute of Shipping Research, Bremen, 4-26.

[3] Law 27/1975 GGI 77A 19-22/04/1975: For Ship's Taxation and the Special Tax for the Development of Merchant Marine, the Settlement of Foreign Companies and Other Related Matters.

[4] Law 1376/1983: Measures for Facing-Out the Shipping Cycle and Related Provisions.

[5] Harlaftis, G. (1993) Greek Shipowners and Greece, 1945-1975: From Separate Development to Mutual Interdependence. Athlone Press, London.

[6] Goulielmos, A.M. (2017) The Great Achievement of Greek-Owned Shipping (1946-2017) and Keynes' Animal Spirits. Modern Economy, 8, 1186-1210.

[7] Goss, R.O. (1968) Investment in Shipping and the Balance of Payments: A Case Study of Import-Substitution Policy. Cambridge University Press, Cambridge, 46-60.

[8] The General Council of British Shipping UK Department of Transport (1986) Analysis of the International Earnings and Expenditure of the UK Shipping Industry.

[9] Varvitsiotis, M. (Date Unknown) To Maintain the Competitiveness of Shipping 
Companies. Nautical Chronicles, 70. (In Greek)

[10] Goulielmos, A.M. (2000) A Proposed Shipping Policy to Counteract Flagging-Out: The Paradigm of Greece. Maritime Economics \& Logistics, 2, 27-47. https://doi.org/10.1057/ijme.2000.5

[11] Goulielmos, A.M. (1997) The Factors Determining the Foreign Exchange Inflow from Shipping Companies in Greece: During the Deep and Prolonged Crisis, 1981-1987. In: Metaxas, B.N., Ed., The Volume of Essays in Memory, University of Piraeus, Piraeus.

[12] Fisser, F. (undated) Konkurrenz der billigen Flaggen. Hansa, 95, 240.

[13] Doganis, R.S. and Metaxas, B.N. (1976) The Impact of Flags of Convenience. Research Report No. 3, Transport Studies Group, Polytechnic of Central London (PCL).

[14] Bergstrand, S.J. (1983) Buy the Flag: Developments in the Open Registry Debate. Transport Studies Group, Discussion Paper No. 13, PCL.

[15] ILO (1974) Argiroffo, E. Flags of Convenience and Substandard Vessels: A Review of the ILO's Approach to the Problem. International Labour Review, 110, Article ID: 437453 .

[16] Metaxas, B.N. (1978) Flags of Convenience and Shipping Strategies, Maritime Research and European Shipping and Shipbuilding. The Netherlands Maritime Institute, 199-219.

[17] Karatzas, N. and Ready, N.P. (1982) The Greek Code of Private Maritime Law.

[18] Ready, N.P. (1998) Ship Registration. 3rd Edition, LLP, London.

[19] UNCTAD (1981) Action on the Question of Open Registries. TD/B/C.4/220.

[20] Power, V.J.G. (1998) EC Shipping Law. 2nd Edition, LLP, London.

[21] Daniolos, G. (1994) A Man Passing-By during the $20^{\text {th }}$ Century. Interview, Argo, 25-32. (In Greek)

[22] Onassis, A. (2018) The Manual of the Greek Shipowner. 131. (In Greek) 


\section{Appendix 1: A Proposed Re-Organization of a SRAA}

The SRAA became long, repeating same things in different places, without a paragraphing system. A re-organization of it, resembling an agreement-has to be done. Also, the new additions in a SRAA is suggested to be in color, so that a previous shipowner to apply for-if he/she so wishes-a modification of his/her SRAA ("recent term" 22).

Preamble

The Ministers of Economy Mr.-and of Merchant Marine \& Island PolicyMMIP Mr.-, hereby approve the terms to which vessel “ARIZONA ${ }^{54 ”}$ will comply with after her registration in the Greek flag, or since temporary marine documents were given to her and raised Greek Flag. These terms are guaranteed by Greek government for their permanency during the entire time of ship's registration.

\subsection{Approval's Legal Framework}

1) Article 13 of law 2687/1953 (for "investment and insurance of capital from abroad" (Government Gazette issue-GGI A'317)), in combination with paragraphs $2 \& 3$ of article 3 of same law.

2) Law 2928/1954 (GGI A’163), which authentically interpreted article 13 of above law.

3) The unanimous opinions of "State's Legal Counsel" numbers 513/07-051955 \& 967/22-09-1956 (in full assembly).

\subsection{The Contracting Parties}

It is hereby agreed, between, (1) State's authorized officials as mentioned below and (2) the representative/guarantor of the owner ${ }^{55}$ of the above mentioned ship.

State's officials are authorized ${ }^{56}$ by: Presidential Decrees-PD 63/2005, 70 \& 73/2015, 123 \& 125/2016, and those in GGI B’ 3696, 3722 \& 3724 and article 67 par. 1 of law 4170/2013 (GGI A'163).

Shipowner's representative/guarantor Mr. ---/---/--- has applied on behalf of ship's owner, representing also company ---, which in turn represents, in Greece, ship's owning company --- established in ---(place), and asked that ship $^{57}$ "ARIZONA": type--- GRT---NRT---, to be registered in Greek Flag under law $2687 / 1953$, in force for vessels greater than 1500 GRT and thus to be capital imported from abroad.

\subsection{The Order of Ministry of MMIP}

Taking also into account: $\Omega \Pi$ : --A $\Lambda \Sigma$-E $\Lambda \mathrm{AKT} / \Delta \Pi \mathrm{N} 4^{\circ}-\Delta \mathrm{NEP} 1$.

\subsection{The Greek Interests in Ship's Company Capital by Majority}

Ship's owner representative declared in writing (date) that in ship's-owning

\footnotetext{
${ }^{54}$ The name is imaginary.

${ }^{55}$ The word for "Owner" stands also for "owners".

${ }^{56} \mathrm{We}$ put a summary here, but these can be written in full.

${ }^{57}$ Including "ships under construction".
} 
company capital, the Greek interest is greater than half.

\subsection{The Terms of the SRAA}

\subsubsection{Permanency of Rules}

The terms of this agreement will be in force over the entire stay of the ship, of par. 1.2, in Greek Registry (Flag), unaltered, except for cases of a more favorable treatment and regardless of any opposing to regulation to be emerged in the legal system in force.

\subsubsection{Free Actions Allowed}

Ship's owner, or her mortgagee-if exists-, has the following 9 (nine) rights to act freely: (I) change ship's flag-automatically-upon written declaration, including dis-registration from (Greek) Flag, for which, however, a specific procedure is followed as described; (II) sell her, (III) register a mortgage on her, (IV) charter her to foreign natural persons or legal entities, with no approval required from Greek authorities; (V) ship's owner and her mortgagee-if existsare free to manage the proceeds and profits, in foreign currency, obtained from the vessel-from sources indicated below-not subject to any restrictions, imposed by Greek laws, or having the obligation to import them into Greece: from (i) ship's operations/chartering, (ii) her sale, (iii) her insurance claims payable due to a marine accident, or from any other cause, and (iv) from a loan on mortgage; (VI) Vessel is not subject to requisition ${ }^{58}$, unless a generalized international war occurs involving Great Powers and Greece, and after Greece declared officially war in line with its international obligations; (VII) Vessel is insured freely by her owner-even if requisitioned by the Greek Government-and regardless if a newer law rules differently; but in case NATO is involved in the war, a specific procedure has to be followed for "war risk insurance", though ship's owner is free to insure her extra in the international insurance market; (IX) ship's seizure is not allowed for any reason and cause by Greek state, or by "legal organizations operating under public law", except for debts created by her owner in relation to her.

1.5.3. Labor/crew issues (8) - this part covers many cases concerning the crew of Greek and foreign nationality and needs a tidy re-arrangement. This will be done by us in another occasion. 1.5.4. Receipts for payments of contributions to Seamen' Pension etc. funds pay no stamp duty (term 9). 1.5 .5 Specifications of vessel's hull and machinery and classification societies allowed (term 10). 1.5.6 Ship's taxation-this is also long (term 12). 1.5.7 The form of the "specific shipping company" (term 16) - this also is extensive and it must include also term 17. 1.5.8 Contributions to IKA (State's Insurance Fund) in case of a ship repair-term 18. 1.5.9 Preferred mortgages-terms 19-20-these are long too and need a tidy re-casting. Term 23 has to be transferred here. 1.5.10 Arbitration-term 21. 1.5.11 Amendments to SRAA. 1.5.12 Validation of a SRAA, when 
ownership changes-term 24. 1.5.13 Allowances from VAT. 1.5.14 For the "specific shipping company" to be transferred to 1.5.7. 1.5.15 SRAA's time validity. 1.5.16 Decision to be published. 1.5.17 Date. 1.5.18 Ministries titles and names. 